\title{
Contact and repellency effects of Rosa damascena Mill. essential oil and its two major constituents against Tetranychus urticae Koch (Acari: Tetranychidae)
}

\author{
Rosa damascena Mill. uçucu yağı ve iki önemli bileşeninin Tetranychus urticae Koch \\ (Acari: Tetranychidae)'de kontakt ve repellent etkileri
}

Sibel YORULMAZ SALMAN ${ }^{1^{*}}$

\section{Summary}

Tetranychus urticae Koch (Acari: Tetranychidae) is a harmful pest of plants worldwide. Essential oils and their components are potential alternatives to the use of synthetic pesticides for two-spotted spider mite control. The aim of this study was to investigate the contact and repellency effects of Rosa damascena essential oil and its two major constituents, geraniol and citronellol, on Tetranychus urticae. A total of 22 compounds were identified by GC-MS analysis, and citronellol (23.43\%) and geraniol (34.91\%) were the main scent compounds of the fresh rose flowers. To determine the contact effect, 1, 5, 10 and $20 \mathrm{ml} / \mathrm{l}$ concentrations of rose essential oil, geraniol and citronellol were applied to egg, nymph and adult life stages of two-spotted spider mites using the leaf disc-spray tower method. To determine the repellency effect, $0.1,1,5$ and $10 \mathrm{ml} / \mathrm{l}$ concentrations of rose essential oil, geraniol and citronellol were applied to nymphs and adults of Tetranychus urticae. The study showed that rose oil, geraniol and citronellol had contact, repellent and ovicidal effects on the different life stages of $T$. urticae. In addition, geraniol was found to have the highest contact, repellent and ovicidal activity, followed by rose oil and citronellol. The results suggest that Rosa damascena essential oil and its two major constituents, geraniol and citronellol, can potentially be used for the management of Tetranychus urticae.

Keywords: Tetranychus urticae, Rosa damascena oil, geraniol, citronellol, acaricidal effect

\section{Özet}

Tetranychus urticae Koch (Acari:Tetranychidae) dünyada bitkiler için önemli bir zararlıdır. İki noktalı kırmızı örümcek mücadelesinde uçucu yağ ve bileşenlerinin kullanımı sentetik pestisitlere alternatif olarak görülmektedir. Bu çalışmada, Rosa damascena uçucu yağı ile iki önemli bileşeni geraniol ve citronellol'ün Tetranychus urticae'de kontakt ve repellent etkileri araştırılmıştır. Taze gül çiçeğinde citronellol (\%23.43) ve geraniol (\%34.91) olmak üzere toplam 22 bileşik belirlenmiştir. Kontakt etki için, gül yağı, geraniol ve citronellol'ün 1, 5, 10 ve $20 \mathrm{ml} / \mathrm{l}$ konsantrasyonları yaprak disk ilaçlama kulesi metodu kullanılarak iki noktalı kırmızı örümceğin yumurta, nimf ve ergin dönemlerine uygulanmıştır. Repellent etki için, gül yağı, geraniol ve citronellol'ün $0.1,1$, $5 \mathrm{ve} 10 \mathrm{ml} / \mathrm{l}$ konsantrasyonları iki noktalı kırmızı örümceğin yumurta, nimf ve ergin dönemlerine uygulanmıştır. Çalışma sonucunda Tetranychus urticae'nin farklı dönemleri üzerinde gül yağı ve iki önemli bileşeni geraniol ve citronello'ün kontakt, repellent ve ovisidal etkilerinin bulunduğu belirlenmiştir. Buna ilaveten en yüksek kontakt, repellent ve ovisidal etki geraniol'de belirlenirken, bunu gül yağı ve citronellol izlemiştir. Çalışma sonucunda elde edilen veriler Rosa damascena uçucu yağı ile iki önemli bileşeni geraniol ve citronellol'ün Tetranychus urticae mücadelesinde potansiyel olarak kullanılabileceğini göstermektedir.

Anahtar sözcükler: Tetranychus urticae, gül yağı, geraniol, citronellol, akarisidal etki

\footnotetext{
${ }^{1}$ Suleyman Demirel University, Agricultural Faculty, Plant Protection Department, Isparta, Turkey

${ }^{2}$ Suleyman Demirel University, Agricultural Faculty, Field Crops Department, Isparta, Turkey

"Sorumlu yazar (Corresponding author) e-mail: sibelyorulmaz@sdu.edu.tr

Alınış (Received): 18.04.2014

Kabul ediliş (Accepted): 06.11.2014
} 


\section{Introduction}

The two-spotted spider mite Tetranychus urticae Koch (Acari: Tetranychidae) is a ubiquitous species that is present worldwide on a wide variety of plants (Helle \& Sabelis, 1985). T. urticae feeds by puncturing cells and draining the contents, subsequently producing a characteristic yellow speckling on leaf surfaces. They also produce a silk webbing, which is clearly visible at high infestation levels (Jeppson et al., 1975). The host plant can be affected in different ways, including a decrease in photosynthesis or by an injection of phytotoxic substances when feeding (Jhonson \& Lyon, 1991). This mite species has been reported to attack approximately 1200 species of plants, of which more than 150 are economically significant (Zhang, 2003). T. urticae is commonly controlled by applications of synthetic pesticides (Van Leeuwen et al., 2004). However, the spider mite's short life cycle, which results in large populations, presents a major challenge in controlling their proliferation. Another challenge is the reduced efficacy of most synthetic pesticides, in part because resistance to synthetic pesticides is quickly selected (Stumpf \& Nauen, 2001; Herron \& Rophail, 2003; Van Leeuwen et al., 2009). Spider mites have evolved resistance to more than 80 acaricides to date, and resistance has been reported in more than 60 countries (Miresmailli et al., 2006). Due to the adverse effects of pesticide use, alternative control methods are being sought for $T$. urticae. A variety of natural bioactive compounds, including several plant essential oils (Calmasur et al., 2006; El Gengaihi et al., 1996; Pontes et al., 2007 a; b), plant extracts (Shi et al., 2006) and microbial secondary metabolites (Villanueva \& Walgenbach, 2006) have been determined to have acaricidal effects (Cavalcanti et al., 2010) on two-spotted spider mites.

Essential oils have a broad spectrum of activity against insects and mites due to the presence of several modes of action, including repellency and antifeedant activities, contact activity, inhibition of molting and respiration, reduction in growth and fecundity, cuticle disruption, and an effect on the invertebrate octopamine pathway (Arnason et al., 1993; Prates et al., 1998; Isman, 2000; Enan, 2001; Akhtar \& Isman, 2004; Isman et al., 2011). Plant essential oils and their constituents have been suggested as alternative sources for mite control products, largely because they constitute a potential source of bioactive chemicals that have been perceived by the general public as relatively safe, pose fewer risks to the environment, and have minimal impacts on human and animal health. Additionally, these compounds often act on multiple and novel target sites, thereby reducing the potential for resistance (Ahn et al., 2006; Isman, 2006; Han et al., 2010). Furthermore, essential oils derived from plants have minimal direct and/or indirect effects on natural enemies (Tunc \& Sahinkaya, 1998; Bostanian et al., 2005; Isman, 2006).

The most important production centers of Rosa damascena Mill. (Damask rose) are Turkey and Bulgaria. R. damascena flowers are handpicked annually in May and June (approximately 35 to 45 days) and the essential oil content of its flower is $0.030-0.050 \%$ (Baydar et al., 2008). Citronellol and geraniol are the major compounds of $R$. damascena oil. These compounds can be obtained from different plant species (Cymbopogon nardus, Pelargonium geranium, etc.) and can also synthetically produced (Jain et al., 2001; Mahalwal \& Ali, 2002). R. damascena is an ornamental species and, in addition to its perfuming effect, several pharmacological properties including anti-HIV, antibacterial, antioxidant, antitussive, hypnotic, antidiabetic, and a relaxant effect on tracheal chains have been reported for this plant (Boskabady et al., 2011). Rose oil has a wide range of uses in industry; however, there are currently no reports of its insecticidal or acaricidal effects on pests.

The aim of this study was to investigate the contact, repellency and ovicidal effects of Rosa damascena essential oil and its two major constituents, geraniol and citronellol, on different life stages of T. urticae under laboratory conditions. 


\section{Materials and Methods}

\section{Plant and chemicals materials}

Fresh flowers of $R$. damascena were handpicked in the early morning hours (from 8:00 to 10:00 a.m.) of the flowering season (May and June, 2013) from the Rose and Rose Products Research and Implementation Center (GULAR) at Suleyman Demirel University in Isparta province of Turkey (latitude $37^{\circ} 45^{\prime} \mathrm{N}$, longitude $30^{\circ} 33^{\prime} \mathrm{E}$, altitude $997 \mathrm{~m}$ ). The fresh flowers were distilled by using a hydro-Clevenger apparatus to obtain the rose oil. Citronellol $\left(\mathrm{C}_{10} \mathrm{H}_{20} \mathrm{O}\right.$, Sigma-Aldrich) and geraniol $\left(\mathrm{C}_{10} \mathrm{H}_{18} \mathrm{O}\right.$, SigmaAldrich) were used as synthetic forms.

\section{Origin and rearing of Tetranychus urticae}

An insecticide-susceptible population of $T$. urticae (German Susceptible Strain, GSS) was obtained from the Rothamstad Experimental Station (England) in 2001 and reared under laboratory conditions to the present without any exposure to pesticides. T. urticae was reared on bean plants in climate chambers with a temperature of $26 \pm 2{ }^{\circ} \mathrm{C}, 50-60 \%$ humidity and a $16: 8$ photoperiod.

\section{Isolation of essential oil}

Fresh rose flowers $(1 \mathrm{~kg})$ and tap water $(3 \mathrm{~L})$ were placed inside in a flask $(6 \mathrm{~L})$ connected to the condenser of a hydro-Clevenger apparatus according to standard procedure described in European Pharmacopoeia (1975). The essential oil and water mixture were separated by decantation. The essential oil was dried with anhydrous sodium sulfate and stored at $4{ }^{\circ} \mathrm{C}$ until used for analysis.

\section{GS-MS analysis of essential oils}

Gas Chromatography/Mass Spectrometry (GC-MS) analysis of the rose samples was performed on a Shimadzu 2010 Plus GC-MS equipped with a Quadrupole (QP-5050) detector. The analysis was performed under the following conditions: capillary column, CP-Wax 52 CB $(50 \mathrm{~m} \times 0.32 \mathrm{~mm}$, film thickness $0.25 \mu \mathrm{m}$ ); injector temperature, $240{ }^{\circ} \mathrm{C}$; detector temperature, $250^{\circ} \mathrm{C}$; oven temperature program, from $60^{\circ} \mathrm{C}$ (10 min. hold) to $220^{\circ} \mathrm{C}$ rising at $2{ }^{\circ} \mathrm{C} / \mathrm{min}$. and increasing to $220^{\circ} \mathrm{C}(11.5 \mathrm{~min}$. hold $)$ rising at $20^{\circ} \mathrm{C} / \mathrm{min}$.; flow speed, $10 \mathrm{psi}$; detector: $70 \mathrm{eV}$; ionization type, El; carrier gas, helium (20 $\mathrm{ml} / \mathrm{min}$.); and sample injected $1 \mu \mathrm{l}$. Identification of constituents was determined by comparison of the retention times of standard substances (by composition of mass spectra) with data from the Wiley, Nist, and Tutor libraries (Stein, 1990).

\section{Contact assay}

The method reported in Miresmailli et al. (2006) was adapted and used to determine the contact effect of essential oils on $T$. urticae adults and nymphs. To ensure homogeneity of the contact effect, $T$. urticae nymphs and the adults of the same age were used. To obtain same-aged nymphs for the experiment, fifteen female individuals were transferred to bean leaf disks prepared in ten Petri dishes (nine-centimeter-diameters) for oviposition. As a result of eggs hatching within twenty four hours of one another, nymphs were the same age for the trials. Eggs left on the leaves became adults of the same age for use in the adult trials. Adult trials were conducted with $T$ urticae adults of the same age. Four concentrations of the essential oils were used to determine the contact effect in either nymphs or adults of $T$ urticae. In trials, 1, 5, 10 and $20 \mathrm{ml} / \mathrm{l}$ concentrations of santolina, sage, rosemary and hyssop were used. Essential oils were diluted to these doses by dissolving them in water containing $0.3 \%$ Tween 20 . Trials were conducted with three repetitions with fifteen individuals in each repetition for each essential oil concentration. Water containing $0.3 \%$-Tween 20 was used as the control in these trials. Either nymphs or adults of $T$. urticae were transferred to bean leaf disks (three-cm diameter) using a thin brush. There was wet cotton under the bean leaf discs to ensure a nine-centimeter radius of moisture. In the trials, Petri dishes containing nymphs or adults of $T$. urticae were treated with pesticides using spraying towers. Essential oil concentrations were administered directly on the nymphs and adults of $T$ urticae. Essential oil solutions were applied on the leaf surface using a spraying tower at one-bar pressure and a rate of 1.2 to $1.6 \mathrm{mg} / \mathrm{cm}^{2}$ (Mansour et al., 1986). Counts of mortality and survival were conducted at 24,48 and $96 \mathrm{~h}$ after treatment. 


\section{Ovicidal effects of essential oils on eggs}

The method of Badawy et al. (2010) was adapted and used to determine the ovicidal effects of essential oils on $T$. urticae eggs. To obtain eggs of the same age for use in the trials, twenty adult females were transferred to bean leaf disks that were prepared in ten Petri plates (nine-centimeter-diameter). After twenty-four hours, adult females were removed and eggs were used in the trials. In trials, 1, 5, 10 and 20 $\mathrm{ml} / \mathrm{l}$ concentrations of santolina, sage, rosemary and hyssop were used and essential oils were diluted to these doses by dissolving in water containing $0.3 \%$ Tween 20 . Trials were conducted with three repetitions using fifteen individuals in each repetition for each essential oil concentration. Water containing $0.3 \%$ Tween 20 was used as a control. Eggs of $T$ urticae were transferred to bean leaf disks (three-centimeter diameter) using a thin brush. There was wet cotton under the bean leaf discs to ensure a nine-centimeter radius of moisture. To measure the contact effect, Petri dishes containing eggs of $T$ urticae were sprayed with pesticides using spraying towers. Essential oil concentrations were administered directly on eggs of $T$ urticae. Essential oil solutions were placed on the leaf surface using a spraying tower at one-bar pressure and a rate of 1.2 to $1.6 \mathrm{mg} / \mathrm{cm}^{2}$ (Mansour et al., 1986). For the ovicidal effect trials, observations continued until last egg in the control group hatched.

\section{Repellency assay}

The methods of Nerio et al. (2009) and Araujo et al. (2012) were adapted and used to determine the repellency effect of essential oils on $T$. urticae nymphs and adults. Same-aged $T$. urticae nymphs and adults were used in the repellency effect assay. Nymphs and adults for this trial were obtained as described for the contact effect trials. The essential oils of $R$. damascena and its two major constituents, geraniol and citronellol were used the repellency effect assays at concentrations of $0.1,1,5$ and $10 \mathrm{ml} / \mathrm{l}$. Essential oils were dissolved in a solution of water and $0.3 \%$ Tween 20 and were diluted to the targeted doses. Half of each sample was placed in the water and $0.3 \%$ Tween 20 solution, and the other half was placed in a Petri dish $(9 \mathrm{~cm})$ with wet cotton and bean leaf discs, which were immersed in essential oil solution. A brush was used to place $T$. urticae nymphs or adults in the middle of the leaf surface on which the application was performed. The experiment was repeated 4 times with 10 individuals per trial. At 2, 6, 24 and $48 \mathrm{~h}$, individuals on the essential oil treated and control portions of the leaf discs were counted.

\section{Data analysis}

Abbott's formula (Abbott, 1925) was used to determine death \% values in contact effect samples.

In the formula, Death value $(\%)=[(A-B) /(A)] \times 100$, A refers to the number of live individuals in the control; $B$ refers to the number of live individuals in the treatment dose. The Repellency effect index $\%$ developed by Obeng-Ofori et al. (1997) was used to calculate the results obtained from the repellency effect tests.

\section{Repellency effect $(\%)=[(\mathrm{Nc}-\mathrm{Nt}) /(\mathrm{Nc}+\mathrm{Nt})] \times 100$}

In this formula, Nc refers to the number of individuals in the control area, and $\mathrm{Nt}$ refers to the number of individuals in the essential oil area. Contact and repellency effects were calculated using Abbott's formula (without percentage) on data obtained from these experiments. The values were subjected to transformation, then, groupings were made by variance analysis (ANOVA) using a statistical analysis software (SAS_v9.1.2 from SAS Institute, Inc., Cary, NC, USA). The significant differences were tested by Duncan's Multiple Range Test $(P \leq 0.05)$. 


\section{Results}

\section{Chemical compositions of essential oils}

According to the GC-MS analysis of the hydrodistilled rose oil, a total of 22 volatile compounds were identified. A high percentage of identified compounds were non-cyclic monoterpene alcohols, represented by geraniol $(34.91 \%)$, citronellol $(23.43 \%)$, and nerol $(15.43 \%)$, and long-chain hydrocarbons (alkanes) represented by nonadecane $(3.01 \%)$, eicosane $(2.52 \%)$, heneicosane $(3.64 \%)$ and tricosane $(1.92 \%)$ (Table 1). Although phenylethyl alcohol (or 2-phenylethanol) was the major scent compound of the fresh flower, it was found at only $0.98 \%$ in the hydrodistilled rose oil. It has been reported that over 100 components have been identified in rose oil by GC and GC-MS analysis. The most important compounds which constitute rose oil have been found to be monoterpene alcohols (citronellol, geraniol, nerol and linalool etc.), hydrocarbons (nonadecane, heneicosane, heptadecane, eicosane and tricosane etc.), sesquiterpenes (humulene and murolene etc.), oxides and ethers (methyl eugenol, etc.), ester and aldehydes (geranyl acetate and geranial, etc.), and phenols (eugenol, etc.) (Anaç, 1984; Kovats, 1987; Başer, 1992; Bayrak \& Akgül, 1994). $\beta$-damascenone, $\beta$-damascene and $\beta$-ionene also contribute to the characteristic odor of rose oil; however these components were found in only trace amounts by GC and GC-MS analysis (David et al., 2006).

Table 1. Essential oil components and rates (\%) of rose oil

\begin{tabular}{llllll}
\hline Components & RT & \% & Components & RT & \% \\
\hline Alpha pinene & 8.1 & 0.24 & Citronellol & $\mathbf{5 1 . 2}$ & $\mathbf{2 3 . 4 3}$ \\
Beta myrcene & 14.0 & 0.23 & Nerol & 53.4 & 15.43 \\
Linalool & 37.7 & 0.81 & Aromadendrene & 54.9 & 0.46 \\
Trans-Caryophyllene & 41.0 & 1.15 & Geraniol & $\mathbf{5 6 . 0}$ & $\mathbf{3 4 . 9 1}$ \\
Terpinen-4-ol & 41.7 & 0.60 & Eicosane & 58.3 & 2.52 \\
Citronellyl acetate & 45.0 & 0.56 & Nonadecene & 59.3 & 3.01 \\
Alpha humulene & 46.1 & 0.61 & Phenethyl alcohol & 60.1 & 0.98 \\
Hexadecane & 46.5 & 1.20 & Methyl eugenol & 65.4 & 0.91 \\
Germacrene D & 48.5 & 1.96 & Heneicosane & 69.0 & 3.64 \\
E-Citral & 49.8 & 0.46 & Eugenol & 73.6 & 1.72 \\
Geranyl acetate & 50.7 & 2.17 & Tricosane & 78.9 & 1.92 \\
\hline
\end{tabular}

\section{Ovicidal effects of the rose essential oil, geraniol and citronellol on eggs}

The effects of rose oil, geraniol and citronellol on $T$. urticae egg hatching are presented in Table 2. It was statistically determined that the effect of rose oil components (geraniol and citronellol) to prevent hatching of $T$. urticae eggs increased with an increase in concentration $(p \leq 0.05)$. Geraniol had the highest ovicidal effect of all concentrations of rose oil and components, while citronellol had the lowest effect. At the $20 \mathrm{ml} / \mathrm{l}$ concentration, the highest effects were $80 \%$ for geraniol, $72.22 \%$ for rose oil and $53.10 \%$ for citronellol.

Table 2. The ovicidal effects of rosa essential oil, geraniol and citronellol on Tetranychus urticae eggs

\begin{tabular}{cccc}
\hline Concentration $(\mathrm{ml} / \mathrm{l})$ & \multicolumn{3}{c}{ Percentage effect (\%) } \\
\cline { 2 - 4 } & $\begin{array}{c}\text { Rosa damascena } \\
\text { (Rose oil) }\end{array}$ & Geraniol & Citronellol \\
\hline 1 & $32.22 \pm 2.20 \mathrm{bD}$ & $44.44 \pm 2.20 \mathrm{aD}$ & $17.77 \pm 2.22 \mathrm{cD}$ \\
5 & $47.78 \pm 2.20 \mathrm{bC}$ & $59.99 \pm 3.91 \mathrm{aC}$ & $33.33 \pm 0.00 \mathrm{cC}$ \\
10 & $63.33 \pm 0.00 \mathrm{aB}$ & $68.88 \pm 2.20 \mathrm{aB}$ & $44.44 \pm 2.21 \mathrm{bB}$ \\
20 & $72.22 \pm 2.20 \mathrm{bA}$ & $80.00 \pm 0.00 \mathrm{aA}$ & $53.10 \pm 1.51 \mathrm{cA}$ \\
\hline
\end{tabular}

Different lower letters on the same row and different upper letters on the same column indicate that there is a significant difference by essential oils and application doses, respectively ( $p \leq 0.05)$. 
Contact and repellency effects of Rosa damascena Mill. essential oil and its two major constituents against Tetranychus urticae Koch (Acari: Tetranychidae)

\section{Contact effect of rose essential oil, geraniol and citronellol}

The contact effects of different concentrations of rose oil, geraniol and citronellol on T. urticae adults are presented in Table 3. Geraniol, which is the most important component of rose oil, had a higher contact effect on twospotted spider mite adults than did rose oil and citronellol at all concentrations and observation times. While the contact effects of the essential oil and its components used in the study were statistically similar to those of rose oil and geraniol at all concentrations at the end of 24 hours, the effect of citronellol was different $(p \leq 0.05)$. At the end of 48 hours, the effect of geraniol was higher than that of rose oil and citronellol at all concentrations and was significantly different $(p \leq 0.05)$. At the end of 96 hours, the contact effect of geraniol was higher than that of rose oil and citronellol at the 1 and $20 \mathrm{ml} / \mathrm{l}$ concentrations. At the 5 and $10 \mathrm{ml} / \mathrm{l}$ concentrations, the contact effects of rose oil and its two components on $T$. urticae were significantly different $(p \leq 0.05)$.

Table 3. Contact effect of rosa essential oil, geraniol and citronellol on Tetranychus urticae adults

\begin{tabular}{|c|c|c|c|c|}
\hline \multirow[t]{2}{*}{ Count time (hour) } & \multirow[t]{2}{*}{ Concentration $(\mathrm{ml} / \mathrm{l})$} & \multicolumn{3}{|c|}{ Contact effect (\%) } \\
\hline & & $\begin{array}{c}\text { Rosa damascena } \\
\text { (Rose oil) }\end{array}$ & Geraniol & Citronellol \\
\hline \multirow{4}{*}{24} & 1 & $17.92 \pm 0.30 \mathrm{aH}$ & $23.17 \pm 1.75 \mathrm{aH}$ & $7.81 \pm 0.67 \mathrm{bG}$ \\
\hline & 5 & $25.39 \pm 5.72 \mathrm{aG}$ & $30.16 \pm 1.59 \mathrm{aGH}$ & $15.28 \pm 2.37 \mathrm{bFG}$ \\
\hline & 10 & $33.33 \pm 0.00 \mathrm{aEF}$ & $37.14 \pm 1.43 \mathrm{aG}$ & $19.44 \pm 3.38 \mathrm{bEF}$ \\
\hline & 20 & $40.47 \pm 4.76 \mathrm{aDE}$ & $45.39 \pm 1.27 \mathrm{aF}$ & $30.14 \pm 5.00 \mathrm{bD}$ \\
\hline \multirow{4}{*}{48} & 1 & $15.87 \pm 2.08 \mathrm{bH}$ & $35.71 \pm 0.00 \mathrm{aG}$ & $14.28 \pm 0.00 \mathrm{bFG}$ \\
\hline & 5 & $30.14 \pm 1.93 \mathrm{bFG}$ & $45.23 \pm 2.38 \mathrm{aF}$ & $25.39 \pm 3.97 \mathrm{bDE}$ \\
\hline & 10 & $42.85 \pm 0.00 \mathrm{bCD}$ & $57.14 \pm 4.12 \mathrm{aDE}$ & $32.57 \pm 2.97$ bD \\
\hline & 20 & $48.16 \pm 4.97 \mathrm{bBC}$ & $69.04 \pm 2.38 \mathrm{aBC}$ & $41.43 \pm 2.97 \mathrm{bC}$ \\
\hline \multirow{4}{*}{96} & 1 & $30.03 \pm 0.73 \mathrm{bFG}$ & $50.00 \pm 0.00 \mathrm{aEF}$ & $23.80 \pm 0.95 \mathrm{bDE}$ \\
\hline & 5 & $52.56 \pm 1.28 \mathrm{bB}$ & $64.28 \pm 0.00 \mathrm{aCD}$ & $44.28 \pm 2.97 \mathrm{cC}$ \\
\hline & 10 & $63.36 \pm 0.92 \mathrm{bA}$ & $76.19 \pm 2.38 \mathrm{aB}$ & $56.19 \pm 0.95 \mathrm{cB}$ \\
\hline & 20 & $70.14 \pm 3.68 \mathrm{bA}$ & $85.71 \pm 0.00 \mathrm{aA}$ & $66.19 \pm 2.38 \mathrm{bA}$ \\
\hline
\end{tabular}

Different lower case letters on the same row and different upper case letters on the same column indicate that there is a significant difference by essential oils and application doses, respectively $(p \leq 0.05)$.

The contact effects of different concentrations of rose oil, geraniol and citronellol on the nymphs of $T$. urticae are presented in Table 4. The contact effect of geraniol on nymphs of $T$. urticae was higher than that of rose oil and citronellol at all concentrations. Furthermore, as the concentration and observational time of all three components increased, the contact effect on the nymphs of twospotted spider mites increased as well. At 24 hours, the effect of geraniol was significantly different from the effects of rose oil and citronellol at the concentrations of $1,5,10 \mathrm{ml} / \mathrm{l}(\mathrm{p} \leq 0.05)$. In contrast, there was no significant difference between the contact effects of all three components at the concentration of $20 \mathrm{ml} / \mathrm{l}$ $(p \leq 0.05)$. At 48 hour, the contact effect of rose oil, geraniol and citronellol on the nymphs of $T$. urticae were statistically similar and these components were in the same group $(p \leq 0.05)$. At the 96 hour observation, geraniol had the highest effect at the concentration of $1 \mathrm{ml} / \mathrm{l}$, while the effects of all three components were statistically similar at the concentrations of 5,10 and $20 \mathrm{ml} / \mathrm{l}(\mathrm{p} \leq 0.05)$.

Table 4. Contact effect of rosa essential oil, geraniol and citronellol on Tetranychus urticae nymphs

\begin{tabular}{ccccc}
\hline Count time (hour) & Concentration (ml/l) & \multicolumn{3}{c}{ Contact effect (\%) } \\
\cline { 2 - 5 } & & $\begin{array}{c}\text { Rosa damascena } \\
\text { (Rose oil) }\end{array}$ & Geraniol & Citronellol \\
\hline \multirow{3}{*}{24} & 1 & $15.72 \pm 1.52 \mathrm{bH}$ & $27.08 \pm 2.94 \mathrm{aE}$ & $12.42 \pm 1.25 \mathrm{bG}$ \\
& 5 & $34.94 \pm 12.13 \mathrm{bFG}$ & $62.20 \pm 10.12 \mathrm{aBC}$ & $36.35 \pm 1.95 \mathrm{bEF}$ \\
& 10 & $61.65 \pm 2.70 \mathrm{bCD}$ & $72.61 \pm 1.19 \mathrm{aAB}$ & $54.44 \pm 2.94 \mathrm{bCD}$ \\
& 20 & $65.47 \pm 5.20 \mathrm{aBC}$ & $72.31 \pm 4.93 \mathrm{aAB}$ & $60.15 \pm 3.26 \mathrm{aA}-\mathrm{D}$ \\
\hline & 1 & $32.27 \pm 8.95 \mathrm{aG}$ & $41.07 \pm 6.64 \mathrm{aD}$ & $28.14 \pm 4.12 \mathrm{aF}$ \\
48 & 5 & $50.73 \pm 10.21 \mathrm{aDE}$ & $53.34 \pm 7.97 \mathrm{aCD}$ & $49.52 \pm 2.38 \mathrm{aDE}$ \\
& 10 & $70.69 \pm 0.73 \mathrm{aA}-\mathrm{C}$ & $73.54 \pm 1.00 \mathrm{aAB}$ & $65.04 \pm 0.38 \mathrm{aA}-\mathrm{C}$ \\
& 20 & $73.07 \pm 2.82 \mathrm{aA}-\mathrm{C}$ & $73.33 \pm 0.00 \mathrm{aAB}$ & $62.85 \pm 2.98 \mathrm{aA}-\mathrm{D}$ \\
\hline & 1 & $47.20 \pm 1.42 \mathrm{bEF}$ & $56.63 \pm 3.05 \mathrm{aC}$ & $39.52 \pm 1.26 \mathrm{bEF}$ \\
96 & 5 & $64.24 \pm 1.49 \mathrm{aB}-\mathrm{D}$ & $65.30 \pm 6.48 \mathrm{aBC}$ & $59.04 \pm 2.38 \mathrm{aBC}$ \\
& 10 & $77.75 \pm 3.46 \mathrm{aAB}$ & $76.51 \pm 1.62 \mathrm{aAB}$ & $70.23 \pm 2.81 \mathrm{aAB}$ \\
& 20 & $83.25 \pm 0.81 \mathrm{aA}$ & $89.10 \pm 2.06 \mathrm{aA}$ & $74.42 \pm 1.19 \mathrm{aA}$ \\
\hline
\end{tabular}

Different lower case letters on the same row and different upper case letters on the same column indicate that there is a significant difference by essential oils and application doses, respectively $(p \leq 0.05)$. 


\section{Repellency effect of rose essential oil, geraniol and citronellol}

The repellent effects of different concentrations of rose oil, geraniol and citronellol components on $T$. urticae adults are presented in Table 5. The repellent effects of rose oil, geraniol and citronellol on $T$. urticae adults in all concentrations decreased with time. While the repellent effects of rose oil and geraniol on $T$. urticae adults were similar at the $0.1 \mathrm{ml} / \mathrm{l}$ concentration at the end of 6,24 and 48 hours, the effect of citronellol was significantly different $(p \leq 0.05)$. Additionally, the repellent effect of all three components at the same concentration at the end of 2 hour significantly different $(p \leq 0.05)$. In contrast, the repellent effects of rose oil and geraniol were statistically similar at the concentrations of 1,5 and $10 \mathrm{ml} / \mathrm{l}$ for all observation times. In contrast, the repellent effect of citronellol was expressed in a different group $(p \leq 0.05)$. The repellent effect of rose oil and geraniol on $T$. urticae adults was $100 \%$ at the $10 \mathrm{ml} / \mathrm{l}$ concentration at the end of 2 hours.

Table 5. Repellency effect of rosa essential oil, geraniol and citronellol on Tetranychus urticae adults

\begin{tabular}{cclcc}
\hline Concentration (ml/l) & Count time (hour) & \multicolumn{3}{c}{ Repellent effect (\%) } \\
\cline { 2 - 4 } & & $\begin{array}{c}\text { Rosa damascena } \\
\text { (Rose oil) }\end{array}$ & Geraniol & Citronellol \\
\hline & 2 & $45.00 \pm 2.90 \mathrm{bGH}$ & $55.00 \pm 2.90 \mathrm{aGH}$ & $27.5 \pm 2.50 \mathrm{cEG}$ \\
0.1 & 6 & $40.00 \pm 0.00 \mathrm{aHI}$ & $45.00 \pm 2.90 \mathrm{al}$ & $22.50 \pm 2.50 \mathrm{bFH}$ \\
& 24 & $32.50 \pm 2.50 \mathrm{alJ}$ & $35.00 \pm 2.90 \mathrm{aJ}$ & $20.00 \pm 0.00 \mathrm{bGH}$ \\
& 48 & $25.00 \pm 2.90 \mathrm{aJ}$ & $32.50 \pm 4.79 \mathrm{aJ}$ & $15.00 \pm 2.90 \mathrm{bH}$ \\
\hline & 2 & $67.50 \pm 2.50 \mathrm{aEF}$ & $67.50 \pm 2.50 \mathrm{aEF}$ & $42.50 \pm 2.50 \mathrm{bD}$ \\
& 6 & $62.50 \pm 2.50 \mathrm{aF}$ & $62.50 \pm 2.50 \mathrm{aFG}$ & $32.50 \pm 2.50 \mathrm{bE}$ \\
& 24 & $52.50 \pm 2.50 \mathrm{aG}$ & $55.00 \pm 2.90 \mathrm{aGH}$ & $30.00 \pm 4.10 \mathrm{bEF}$ \\
& 48 & $45.00 \pm 2.90 \mathrm{aGH}$ & $47.50 \pm 4.79 \mathrm{aHI}$ & $25.00 \pm 2.90 \mathrm{bEG}$ \\
\hline & 2 & $87.50 \pm 2.50 \mathrm{aB}$ & $82.50 \pm 2.50 \mathrm{aBC}$ & $67.50 \pm 2.50 \mathrm{bAB}$ \\
& 6 & $80.00 \pm 0.00 \mathrm{aBD}$ & $80.00 \pm 0.00 \mathrm{aCD}$ & $62.50 \pm 2.50 \mathrm{bBC}$ \\
& 24 & $75.00 \pm 2.90 \mathrm{aDE}$ & $72.50 \pm 2.50 \mathrm{aDE}$ & $60.00 \pm 0.00 \mathrm{bBC}$ \\
& 48 & $65.00 \pm 2.90 \mathrm{aF}$ & $60.00 \pm 0.00 \mathrm{aFG}$ & $45.00 \pm 2.90 \mathrm{bD}$ \\
\hline & 2 & $100.00 \pm 0.00 \mathrm{aA}$ & $100.00 \pm 0.00 \mathrm{aA}$ & $75.00 \pm 2.90 \mathrm{bA}$ \\
& 6 & $97.50 \pm 2.50 \mathrm{aA}$ & $90.00 \pm 5.65 \mathrm{aB}$ & $72.50 \pm 2.50 \mathrm{bA}$ \\
& 24 & $85.00 \pm 2.90 \mathrm{aBC}$ & $80.00 \pm 0.00 \mathrm{aCD}$ & $67.50 \pm 2.50 \mathrm{bAB}$ \\
& 48 & $77.50 \pm 2.50 \mathrm{aCD}$ & $75.00 \pm 2.90 \mathrm{aDE}$ & $55.00 \pm 2.90 \mathrm{bC}$ \\
\hline
\end{tabular}

Different lower case letters on the same row and different upper case letters on the same column indicate that there is a significant difference by essential oils and application doses, respectively $(p<0.05)$.

The repellent effects of different concentrations of rose oil, geraniol and citronellol on $T$. urticae nymphs are presented in Table 6 . There was no statistically significant difference between the repellent effects of the $0.1 \mathrm{ml} / \mathrm{l}$ concentrations of rose oil, geraniol and citronellol on $T$. urticae nymphs at the end of 2 and 6 hours $(p \leq 0.05)$. In contrast, rose oil and geraniol effect had a similar effect at the same concentration at the end of 24 hours, while the effect of citronellol was presented in a different statistical group ( $p \leq 0.05$ ). At the end of 48 hours at the $0.1 \mathrm{ml} / \mathrm{l}$ concentration, the repellent effects of all three components on $T$. urticae nymphs were significantly different $(p \leq 0.05)$. The effect of geraniol was higher than rose oil and citronellol at the $1 \mathrm{ml} / \mathrm{l}$ concentration at the end of 2 and 24 hour. The repellent effects of all three components at the end of 6 hours were statistically similar. At the end of 48 hours, the effect of rose oil and geraniol were similar, however the effect of citronellol was significantly different from the other two components. The repellent effect of geraniol on $T$. urticae nymphs at all observation times was $100 \%$ compared to the 5 and $10 \mathrm{ml} / \mathrm{l}$ concentrations. The repellency of rose oil and the two components, especially at the $10 \mathrm{ml} / \mathrm{l}$ concentration, were $100 \%$, excluding citronellol at the 48 hour observation. 
Contact and repellency effects of Rosa damascena Mill. essential oil and its two major constituents against Tetranychus urticae Koch (Acari: Tetranychidae)

Table 6. Repellency effect of rosa essential oil, geraniol and citronellol on Tetranychus urticae nymphs

\begin{tabular}{ccccc}
\hline Concentration (ml/I) & Count time (hour) & \multicolumn{3}{c}{ Repellent effect (\%) } \\
\cline { 2 - 5 } & & $\begin{array}{c}\text { Rosa damascena } \\
\text { (Rose oil) }\end{array}$ & Geraniol & Citronellol \\
\hline & 2 & $75.00 \pm 5.00 \mathrm{aBC}$ & $80.00 \pm 5.60 \mathrm{aBC}$ & $70.00 \pm 8.16 \mathrm{aB}$ \\
0.1 & 6 & $70.00 \pm 5.60 \mathrm{aC}$ & $65.00 \pm 5.00 \mathrm{aC}$ & $60.00 \pm 0.00 \mathrm{aCD}$ \\
& 24 & $45.00 \pm 5.00 \mathrm{aD}$ & $55.00 \pm 5.00 \mathrm{aCD}$ & $25.00 \pm 5.00 \mathrm{bEF}$ \\
& 48 & $30.00 \pm 5.60 \mathrm{bE}$ & $45.00 \pm 10.00 \mathrm{aD}$ & $15.00 \pm 5.00 \mathrm{cF}$ \\
\hline & 2 & $85.00 \pm 9.67 \mathrm{bAB}$ & $100.00 \pm 0.00 \mathrm{aB}$ & $80.00 \pm 0.00 \mathrm{bA}$ \\
1 & 6 & $70.00 \pm 12.60 \mathrm{aC}$ & $80.00 \pm 0.00 \mathrm{aB}$ & $80.00 \pm 0.00 \mathrm{aB}$ \\
& 24 & $55.00 \pm 9.80 \mathrm{abD}$ & $65.00 \pm 5.00 \mathrm{aC}$ & $50.00 \pm 5.60 \mathrm{bD}$ \\
& 48 & $50.00 \pm 5.60 \mathrm{aD}$ & $60.00 \pm 0.00 \mathrm{aC}$ & $30.00 \pm 5.60 \mathrm{bE}$ \\
\hline & $100.00 \pm 0.00 \mathrm{aA}$ & $100.00 \pm 0.00 \mathrm{aA}$ & $100.00 \pm 0.00 \mathrm{aA}$ \\
& 6 & $100.00 \pm 0.00 \mathrm{aA}$ & $100.00 \pm 0.00 \mathrm{aA}$ & $100.00 \pm 0.00 \mathrm{aA}$ \\
& 24 & $100.00 \pm 0.00 \mathrm{aA}$ & $100.00 \pm 0.00 \mathrm{aA}$ & $90.00 \pm 5.60 \mathrm{aAB}$ \\
& 48 & $100.00 \pm 0.00 \mathrm{bBC}$ & $100.00 \pm 0.00 \mathrm{aA}$ & $65.00 \pm 5.00 \mathrm{cC}$ \\
\hline & 2 & $100.00 \pm 0.00 \mathrm{aA}$ & $100.00 \pm 0.00 \mathrm{aA}$ & $100.00 \pm 0.00 \mathrm{aA}$ \\
& 6 & $100.00 \pm 0.00 \mathrm{aA}$ & $100.00 \pm 0.00 \mathrm{aA}$ & $100.00 \pm 0.00 \mathrm{aA}$ \\
& 24 & $100.00 \pm 0.00 \mathrm{aA}$ & $100.00 \pm 0.00 \mathrm{aA}$ & $100.00 \pm 0.00 \mathrm{aA}$ \\
& 48 & $100.00 \pm 0.00 \mathrm{aA}$ & $80.00 \pm 0.00 \mathrm{bB}$ \\
\hline
\end{tabular}

Different lower case letters on the same row and different upper case letters on the same column indicate that there is a significant difference by essential oils and application doses, respectively $(p<0.05)$.

\section{Discussion}

Many essential oils and their major components are emerging as pest control agents due to their insecticidal, acaricidal, repellent, contact and antifeedant properties (Saxena, 1989; Isman, 2000; Barnard \& Xue, 2004; Papachristos et al., 2004). This study analyzed the contact, repellent and ovicidal effects of rose oil and its two important components, geraniol and citronellol, on different life stages of $T$. urticae.

Rose oil and its two important components, geraniol and citronellol, were found to have a contact effect on T. urticae adults and nymphs. Rose oil, geraniol and citronellol concentrations that were applied, especially after 96 hours, had high lethal effects on adults and nymphs of $T$. urticae. Geraniol had the highest contact effect on adults and nymphs of $T$. urticae at all concentrations, followed by rose oil and citronellol. According to the GS-MS analysis, geraniol and citronellol are the most prevalent components of rose oil (34.91\% and $23.43 \%$, respectively). Overall, geraniol, which is most abundant component of rose oil, shows the highest effect on $T$. urticae. Although citronellol, which is the second most important component of rose oil, has a significant contact effect on adults and nymphs of $T$. urticae, this effect was lower than for that of rose oil. This supports the assertion that citronellol has a role in the contact effect of rose oil on adults and nymphs of $T$. urticae; however, geraniol, which is present in rose oil at a higher percentage, has a more significant role in the contact effect on $T$. urticae. The effect of the nerol component, which is the third most abundant component in rose oil $(15.43 \%)$, should also be analyzed. Similar results were found for the ovicidal effects of rose oil, geraniol and citronellol on $T$. urticae eggs. Attia et al. (2012) reported that major compounds in essential oils play a role in the acaricidal effects of those oils. Essential oils and monoterpenoids have been reported to have an acaricidal effect on twospotted spider mites (Sanchez-Ramos \& Castanera, 2000; Rasikari et al., 2005; Miresmailli et al., 2006; Badawy et al., 2010; Cavalcanti et al., 2010; Sertkaya et al., 2010; Roh et al., 2011). Although the literature contains no reports on the insecticidal or acaricidal activity of rose oil, there is some research on geraniol, which is contained in some essential oils. In a study that used a-pinene, geraniol, limonene and $\rho$-cymen monoterpenoids, Traina et al. (2005) reported that geraniol had a higher acaricidal activity on Otodectes cynotis (Acari: Psoroptidae) than other monoterpenoids. Comparing the activities of geraniol monoterpenoid and benzyl benzoate acaricide on T. putrescentiae, Jeon et al. (2009) reported that geraniol had a higher acaricide effect. Similarly, in our study, geraniol was found to have a high acaricidal effect. Badawy et al. (2010) showed that limonene, carvone, linalool, fenchone, 1-8-cineole, myrcene, geraniol and camphor monoterpenoids showed a $70.6 \%-6.3 \%$ ovicidal effect on $T$. urticae eggs. In agreement with other reports, this study found that the ovicidal effect of geraniol on $T$. urticae eggs was higher than that of rose oil and citronellol. 
Repellence is another advantageous property of essential oils; some contain numerous secondary metabolites that can deter attacks from insects and general herbivores (Isman, 2000). Repellency of the rose oil, geraniol and citronellol on $T$. urticae adults and nymphs at all concentrations were observed to be high at 2 hours. However, this effect decreased with time. The repellent effects of rose oil, geraniol and citronellol on $T$. urticae nymphs were higher than their effects on adults. All three components had $100 \%$ repellency in nearly all of the 5 and $10 \mathrm{ml} / \mathrm{l}$ concentrations. Similar to the contact effect, geraniol had the highest repellent effect on twospotted spider mite adults and nymphs, followed by rose oil and citronellol. Similar to our findings, other reports have shown that some essential oils and components have repellent effects against pests. According to the results of Mansour et al. (1986), different concentrations of acetonic solutions of essential oils from 14 species of Labiatae caused mortality and induced repellency in adult females of the Tetranychus cinnabarinus Boisd. (Acari: Tetranychidae) and oviposition was also reduced. Hori \& Komatsu (1997) found that Rosmarinus officinalis L. volatile oil and its principle component 1,8-cineole was repellent against Neotoxoptera formosana (Takahashi) (Homoptera: Aphididae). Jantan \& Zaki (1998) reported that formulations made of Cinnamomum camphora Linnaeus (Lauraceae), Mentha pulegium Linnaeus (Labiatae) essential oils and camphor components had long-term repellent effects against pests, and some monoterpenoids such as a-pinene, limonene, terpinolene, citronellol, citronellal and camphor also had repellent effects. Araujo et al. (2012) reported that Piper aduncum essential oil and its principle components (nerolidol, $\alpha$-humulene and $\beta$ caryophyllene) did not show a repellent effect in $T$. urticae. Conclusive research has shown geraniol to be an effective plant-based mosquito repellent and an insecticide for controlling pests with low mammalian toxicity and biodegradability (Omolo et al., 2004; Chen \& Viljoen, 2010).

Different concentrations of rose oil and its two important components geraniol and citronellol were found to have contact and repellent effects on T. urticae adult and nymphs and ovicidal effects on eggs. Furthermore, in all experiments on contact, repellent and ovicidal effects, geraniol was found to have the highest effect, followed by rose oil and citronellol. Based on these findings, it is believed that geraniol and citronellol play a significant role in the contact and repellent effects of rose oil on $T$. urticae; however, the effect of geraniol, which is more abundant in rose oil, was higher than that of citronellol. In addition, none of the concentrations of rose oil were observed to have a phytotoxic effect on the leaves of beans used in Petri dishes. Many plant essential oils and their components have a broad spectrum of activity against mites and other pests (Attia et al., 2013). It has been recognized that essential oils and their constituents can be developed into products suitable for integrated pest management because some of them are selective for pests, have few harmful effects on non-target organisms, are environmentally non-persistent, and have behavioral (repellence and feeding deterrence) and physiological efficacy (acute toxicity and developmental disruption) against various types of pest complexes (Ahn et al., 2006; Isman, 2006). Furthermore, as essential oils are a mixture of terpenoid compounds, the rapid resistance development observed in two-spotted spider mites will be slower than for insecticides containing only one active ingredient. However, because large amounts of rose material are necessary for rose oil extraction, it is a very expensive essential oil. Therefore, the use of rose oil as an alternative to pesticides against $T$. urticae is not considered possible, as it will considerably increase agricultural inputs. In contrast, geraniol and citronellol, which are two important components of rose oil and have important contact and repellent effects on $T$. urticae, could be included in pest control programs because they can be synthetically produced. However, the number of studies in laboratory and field conditions should be increased to test the appropriateness of these compounds in pest control programs. In addition, this study is significant as it is the first study to analyze the potential use of rose oil to control $T$. urticae. 
Contact and repellency effects of Rosa damascena Mill. essential oil and its two major constituents against Tetranychus urticae Koch (Acari: Tetranychidae)

\section{References}

Abbot, W. S., 1925. A method of comparing the effectiveness of an insecticide. Journal of Economic Entomology, 18: 265-267.

Ahn, Y. J., S.I. Kim, H.K. Kim \& J.H. Tak, 2006. "Naturally Occurring House Dust Mites Control Agents: Development and Commercialization, 269-289" In: Naturally Occurring Bioactive Compounds (Eds. M. Rai \& M. C. Carpinella). Elsevier, London, UK, 422 pp.

Akhtar, Y. \& M. B. Isman, 2004. Comparative growth inhibitory and antifeedant effects of plant extracts and pure allelochemicals on four phytophagous insect species. Journal of Applied Entomology, 128: 32-38.

Anaç, O., 1984. Gas chromatographic analysis on Turkish rose oil, absulute and concrete. Perfumer \& Flavorist 9:114.

Araujo, M. J. C., C. A. G. Camara, F. S. Born, M. M. Moraes \& C. A. Badji, 2012. Acaricidal activity and repellency of essential oil from Piper aduncum and its components against Tetranychus urticae. Experimental and Applied Acarology, 57:139-155.

Arnason, J. T., S. MacKinnon, A. Durst, B. J. R. Philogene, C. Hasbun, P. Sanchez, L. Poveda, L., San Roman, M. B. Isman \& C. Satasook, 1993. "Insecticides in tropical plants with non-neurotoxic modes of action, 107-131". In: Phytochemical Potential of Tropical Plants (Eds. K.R., Downum, J. T., Romeo \& H. A. Stafford). Plenum, New York, 510 pp.

Attia, S., L. K. Grisssa, G.Z. Ghrabi, A. C. Mailleux, G. Lognay \& T. Hance, 2012. Acaricidal activity of 31 essential oils extracted from plants collected in Tunisia. Journal Essential Oil Research, 24:279-288.

Attia, S., L. K. Grissa, G. Lognay, E. Bitume, T. Hance \& A. C. Mailleux, 2013. A review of the major biological approaches to control the worldwide pest Tetranychus urticae (Acari: Tetranychidae) with special reference to natural pesticides Biological approaches to control Tetranychus urticae. Journal of Pest Science, 86:361-386.

Badawy, M. E. I., S. A. A. El-Arami \& S. A. M. Abdelgaleil, 2010. Acaricidal and quantitative structure activity relationship of monoterpenes against the two-spotted spider mite, Tetranychus urticae. Experimental and Applied Acarology, 52:261-274.

Başer, K.H.C., 1992. Turkish rose oil. Perfumer \& Flavorist, 17: 45-52.

Baydar, H., H. Schulz, H. Kruger, S. Erbaş \& S. Kıneci, 2008 Influence of fermentation time, hydro-distillation time and fractions on essential oil composition of Damask rose (Rosa damascena Mill.). Journal of Essential Oil Bearing Plants, 11(3):224-232.

Bayrak, A. \& A. Akgül, 1994. Volatile oil composition of Turkish rose (Rosa damascena Mill.). Journal of Science Food Agriculture, 64: 441-448.

Bernard, D. R. \& R. Xue, 2004.Laboratory evulation of mosquito repellents against Aedes albopictus, Culex nigripalpus and Ochlerotatus triseriatus (Diptera:Culicidae). Journal of Medical Entomology, 41: 726-730.

Boskabady, M. H., M. N. Shafei, Z. Saberi \& S. Amini, 2011. Pharmacological effects of Rosa damascena. Iranian Journal of Basic Medical Sciences, 14(4): 295-307.

Bostanian, N. J., M. Akalach \& H. Chiasson, 2005. Effects of a chenopodium-based botanical insecticide/acaricide on Orius insidiosus (Hemiptera: Anthocoridae) and Aphidius colemanii (Hymenoptera: Braconidae). Pest Management Science, 61: 979-984.

Calmasur, O., I. Aslan \& F. Sahin, 2006. Insecticidal and acaricidal effect of three Lamiaceae plant essential oils against Tetranychus urticae Koch and Bemisia tabaci Genn. Indian Crops Production, 23: 140-146.

Cavalcanti, S. C. H., S. Niculau-Edos, A. F. Blank, C. A. G. Camara, I. N. Araujo \& P. B. Alves, 2010. Composition and acaricidal activity of Lippia sidoides essential oil against two-spotted spider mite (Tetranychus urticae Koch). Bioresour Technology, 101: 829-832.

Chen, W. \& A. M. Viljoen, 2010. Geraniol-Areview of a commercially important fragrance material. South African Journal of Botany, 76: 643-651.

David, F., C. De-Clercq \& P. Sandra, 2006. GC/MS/MS Analysis of $\beta$-damascenone in Rose Oil. Varian GC/MS App., Note, $52 \mathrm{pp}$. 
ElGengaihi, S. E., S. A. A. Amer \& S. M. Mohamed, 1996. Biological activity of thyme oil and thymol against Tetranychus urticae Koch. Anz Schadlingskd Pfl, 69: 157-159.

Enan, E., 2001. Insecticidal activity of essential oils: octopaminergic sites of action. Comparative Toxicology Pharmacology, 130: 325-337.

European Pharmacopoeia, 1975. Maissonneuve Sainte Ruffine 3: 68.

Han, J., B. R. Choi, S. G. Lee, Kim \& Y. J. Sland-Ahn, 2010. Toxicity of plant essential oils to acaricide-susceptible and -resistant Tetranychus urticae (Acari: Tetranychidae) and Neoseiulus californicus (Acari: Phytoseiidae). Journal of Economic Entomology, 103: 1293-1298.

Helle, W. \& M. W. Sabelis, 1985. Spider Mites. Their Biology, Natural Enemies and Control. World Crop Pests 1B., Elsevier, Amsterdam, $232 \mathrm{pp}$.

Herron, G. A. \& J. Rophail, 2003. First detection of chlorfenapyr (Secure) resistance in two-spotted spider mite (Acari:Tetranychidae) from nectarines in an Australia orchard. Experimental and Applied Acarology, 31: 131134.

Hori, M. \& H. Komatsu, 1997. Repellency of rosemary oil and its components against the onion aphid, Neotoxoptera formosana (Takahashi) (Homoptera: Aphididae). Applied Entomology Zoology, 32: 303-310.

Isman, M. B., 2000. Plant essential oils for pest and disease management. Crop Protectection, 19: 603-608.

Isman, M. B., 2006. Botanical insecticides, deterrents, and repellents in modern agriculture and increasingly regulated world. Annual Review Entomology, 51:45-56.

Isman, M. B., S. Miresmailli \& C. M. Machial, 2011. Commercial opportunities for pesticides based on plant essential oils in agriculture, industry and consumer products. Phytochemical Reviwer, 10: 197-204.

Jain, N., K. K. Aggarwal, K. V. Syamasundar, S. K. Srivasta \& S. Kumar, 2001. Essential oil composition of geranium (Pelargonium sp.) from the plains of Northern India. Flavour and Fragrance Journal, 16(1): 44-46.

Jantan, I. \& Z. M. Zaki, 1998. Development of environment-friendly insect repellents from the leaf olls of selected malaysian plants. Asean Reviwer Biodiversity and Environmental Conser , 3: 1-7.

Jeppson, L. R., H. H. Keifer \& E. W. Baker, 1975. Mites Injurious to Economic Plants-I. University of California Press, Berkeley, $250 \mathrm{pp}$.

Jeon, J. H., C. H. Lee \& H. S. Lee 2009. Food protective effect of geraniol and its congeners against stored food mites. Journal of Food Production, 72: 1468-1471.

Jhonson, W. T. \& H. H. Lyon, 1991. Insects That Feed on Trees and Shrubs. Cornell University, Ithaca, 125 pp.

Kovats, E., 1987. Composition of essential oils. part 7: Bulgarian oil of rose (Rosa damascena Mill.). Journal Chromatography, 406: 185-222.

Mahalwal, V. S. \& M. Ali, 2002. Volatile constituents of Cymbopogon nardus (Linn.) Rendle. Flavour and Fragrance Journal, 18(1): 73-76.

Mansour, F., U. Ravid \& E. Putievsky, 1986. Studies of the effects of essential oils isolated from 14 species of Labiatae on the carmine spider mite, Tetranychus cinnabarinus. Phytoparasitica, 14: 137-142.

Miresmailli, S., R. Bradbury \& M. B. Isman, 2006. Comparative toxicity of Rosmarinus officinalis L. essential oil and blends of its major constituents against Tetranychus urticae Koch (Acari: Tetranychidae) on two different host plants. Pest Management Science, 62: 366-371.

Nerio, L. S., J. Olivero-Verbel \& E. Stashenko, 2009. Repellent activity of essential oils from seven aromatic grown in Colombia against Sitophilus zeamais Motschulsky (Coleoptera). Journal of Stored Product Research, 45: 212-214.

Obeng-Ofori, D., C. H. Reichmuth, J. Bekele \& A. Hassanali, 1997. Biological activity of 1,8-cineole, a major component of essential oil of Ocimum kenyense (Ayobangira) against stored product beetles. Journal of Applied Entomology, 121: 237-243.

Omolo, M. O., D. Okinyo, I. O. Ndiege, W. Lwande \& A. Hassanali, 2004. Repellency of essential oils of some Kenyan plants against Anopheles gambiae. Phytochemistry, 65: 2797-2802. 
Contact and repellency effects of Rosa damascena Mill. essential oil and its two major constituents against Tetranychus urticae Koch (Acari: Tetranychidae)

Papachristos, D., K. Karamaniol, D. Stamopoulos \& U. Menkissoglu-Spirudi, 2004. The relationship between the chemical composition of three essential oils and their insecticidal activity against Acanthoscelides obtectus (Say). Pest Management Science, 60: 514-520.

Pontes, W. J. T., J. C. S. Oliveira, C. A. G. Camara, M. G. C. Gondim, J. V. Oliveira \& M. O.E. Schwartz, 2007a. Acaricidal activity of the essential oils of leaves and fruits of Xylopia sericea St. Hill. on the two spotted spider mite (Tetranychus urticae Koch). Quim Nova, 30: 838-841.

Pontes, W. J. T., J. C. S. Oliveira, C. A. G. Camara, A. C. H. R. Lopes, M. G. C. Gondim, J. V. Oliveira \& M. O. E. Schwartz, 2007b. Composition and acaricidal activity of the resin's essential oil of Protium bahianum Daly against two spotted spider mite (Tetranychus urticae). Journal of Essential Oil Research, 19: 379-383.

Prates, H.T., J. P. Santos, J. M. Waquil, J. D. Fabris, A. B. Oliveira \& J. E. Foster, 1988. İnsecticidal activity of monoterpenes against Rhysopertha dominica (F.) and Tribolium castaneum (Herbst.). Journal of Stored Product Research, 34: 243-249.

Rasikari, H. L., D. N. Leach, P. G. Waterman, R. N. Spooner-Hart, A. H. Basta \& L. K. Banbury, 2005. Acaricidal and cytotoxic activities of extracts from selected genera of Australian Lamiaceae. Journal of Economic Entomology, 98: 1259-1266.

Roh, H. S., E. G. Lim, J. Kim \& C. G. Park, 2011. Acaricidal and oviposition deterring effects of santalol identified in sandalwood oil against the two-spotted spider mite, Tetranychus urticae Koch (Acari: Tetranychidae). Journal of Pest Science, 84: 495-501.

Sanchez-Ramos, I. \& P. Castanera, 2000. Acaricidal activity of natural monoterpenes on Tyrophagus putrescentiae (Schrank), a mite of stored food. Journal of Stored Product Research, 37: 93-101.

Saxena, B. P., 1989. "Insecticides from Neem, 110-135" In: Insecticides of Plant Origin. (Eds. J. T., Arnason, B. J. R., Philogene \& P., Morand). Am Chemical Society, 232 pp.

Sertkaya E., K. Kaya \& S. Soylu, 2010. Acaricidal activities of the essential oils from several medicinal plants against the carmine spider mite (Tetranychus cinnabarinus Boisd.) (Acarina: Tetranychidae) Industrial Crops and Product, 31: 107-11.2

Shi, G. L., L. L, Zhao, S. Q. Liu, H. Cao, S. R. Clarke \& J. H. Sun, 2006. Acaricidal activities of extracts of Kochia scoparia against Tetranychus urticae, Tetranychus cinnabarinus, and Tetranychus viennensis (Acari: Tetranychidae). Journal of Economic Entomology, 99: 858-863.

Stein, S. E., 1990. National Institute of Standards and Technology (NIST) Mass Spectral 418 Database and Software, Version 3.02, Juen USA.

Stumpf, N., C. P. W. Zebitz, W. Kraus, G. D. Moores \& N. Nauen, 2001. Resistance to organophosphaths and biochemical genotyping of Acetylcholinesterases in Tetranychus urticae (Acari: Tetranychidae). Pest Biochemical Physioogyl, 69: 131-142

Triana, O., C. Cafarchia, G. Capelli, N. S. lacobellis \& D. Otranto, 2005. In vitro acaricidal activity of four monoterpenes and solvents against Otodectes cynotis (Acari:Psoroptidae). Experimental and Applied Acarology, 37: 141-146.

Tunc, I. \& S. Sahinkaya, 1998. Sensivity of two greenhouse pests to vapours of essential oils. Entomology Experimental Applied, 86: 183-187.

Van Leeuwen, T., V. Stillatus \& L. Tirry, 2004. Genetic analysis and cross-resistance spectrum of a laboratory selected chlorfenapyr resistant strain of two-spotted spider mite (Acari:Tetranychidae). Experimental and Applied Acarology, 32: 249-261.

Van Leeuwen, T., J. Vontas, A. Tsagkarakou \& L. Tirry, 2009. "Mechanisms of Acaricide Resistance in the Two Spotted Spider Mite Tetranychus urticae, 347-393". In: Biorational Control of Arthropod Pests. (Eds. I., Ishaaya \& A. R., Horowitz) Springer, New York, 400 pp.

Villanueva, R. T. \& J. F. Walgenbach, 2006. Acaricidal properties of spinosad against Tetranychus urticae and Panonychus ulmi (Acari: Tetranychidae). Journal of Economic Entomology, 99: 843-849.

Zhang, Z., 2003. Mites of Greenhouses: Identification, Biology and Control. CABI Publishing, Wallingford, 256 pp. 